\title{
Aerosols in Dentistry and Minimizing Their Production and Exposure in COVID-19 Era
}

\author{
Ameet Mani ${ }^{1}$, Preeti P Kale ${ }^{2}$, Raju Anarthe ${ }^{3}$, Gowri S Pendyala ${ }^{4}$, Pranay Thakkur ${ }^{5}$, Anuraga Ekharamantri ${ }^{6}$
}

\begin{abstract}
The widespread public health concern that has gripped the complete international community is related to recent spread of severe acute respiratory syndrome coronavirus 2 (SARS-CoV-2) and its associated coronavirus disease. Despite all the world's efforts to contain the coronavirus disease spread, the outbreak is still on a rise because of the community spread pattern of this infection. This infection is believed to have originated in bats and pangolins and later transmitted to human races thereafter. Once this virus enters the human body, it is abundantly present in nasopharyngeal secretions and salivary secretions of infected patients, and its spread is predominantly thought to be respiratory droplet/ contact in nature. Dental professionals being in the frontline for acquiring infections may encounter patients with suspected or confirmed SARS-CoV-2 infection. Dental professionals will have to act diligently not only to provide care but at the same time prevent further nosocomial spread of infection also. Thus, this review article aims to provide a brief overview of coronavirus disease 2019 (COVID-19) and dental aerosols and guidelines in minimizing aerosol production and exposure.

Keywords: Coronavirus, Coronavirus disease 2019, Dental, Endodontics, Severe acute respiratory syndrome.

CODS Journal of Dentistry (2020): 10.5005/jp-journals-10063-0066
\end{abstract}

\section{INTRODUCTION}

\section{Background}

Coronavirus disease 2019 (COVID 19): Coronaviruses make up a large family of viruses, that can infect birds, mammals, including humans as per the reports of the World Health Organization (WHO). These coronavirus categories have been responsible for several outbreaks around the world in the recent century, including the severe acute respiratory syndrome (SARS) pandemic of 2002 to 2003 and the Middle East respiratory syndrome (MERS) outbreak in the South Korea in the year 2015. Most recently, a novel coronavirus (SARS-CoV-2, also known as COVID-19) triggered an outbreak in China in December 2019 which lead to sparking international concern around this disease. some coronaviruses types have caused devastating epidemics, others cause mild to moderate respiratory infections like the common cold. Coronaviruses belong to the subfamily Corona virinae in the family Corona viridae. There are currently seven recognized types of coronavirus that can infect humans. The other rarer strains that cause more severe complications include MERS-CoV, which causes MERS, and SARS-CoV, the virus responsible for the SARS.

In 2019, a new strain relatively dangerous called SARS-CoV-2, designated as 2019-nCoV, started circulating in the community, causing the disease COVID-19. This novel coronavirus emerged in Wuhan, China, at the end of 2019. At a media briefing on March 11, 2020, the Director-General of the WHO declared COVID-19 outbreak a pandemic. ${ }^{1}$

The asymptomatic incubation period of coronavirus is estimated to be between 2 and 14 days; few studies reported up to 24 days of incubation period. The most common symptoms of coronavirus disease are fever, tiredness, dry cough and shortness of breath, impairment in smell (anosmia) and taste (ageusia). Of about $>80 \%$ of cases are mild and recover from the

\begin{abstract}
${ }^{1-4}$ Department of Periodontology, Rural Dental College, Loni, Ahmednagar, Maharashtra, India

${ }^{5}$ Department of Oral and Maxillofacial Surgery, Rishiraj Dental College, Bhopal, Madhya Pradesh, India

${ }^{6}$ Department of Periodontology, Saraswati Dhanantari Dental College and Hospital, Parbhani, Maharashtra, India
\end{abstract}

Corresponding Author: Preeti P Kale, Department of Periodontology, Rural Dental College, Loni, Ahmednagar, Maharashtra, India, Phone: +91 8956445655, e-mail: preetikale20jan@gmail.com

How to cite this article: Mani A, Kale PP, Anarthe R, et al. Aerosols in Dentistry and Minimizing Their Production and Exposure in COVID-19 Era. CODS J Dent 2020;12(2):41-44.

Source of support: Nil

Conflict of interest: None

disease without any special treatment. However, around $15 \%$ of cases are considered to be severely ill and the remaining $5 \%$ are categorized as critically ill cases. In severe and critical cases, the acute respiratory disease can lead to pneumonia, kidney failure, and even death. ${ }^{2}$

In mild COVID-19 cases, usually symptomatic treatment and home isolation are enough. Oxygen therapy is the major intervention for patients with severe COVID-19 patients. Critical case management on the other hand is case dependent and will usually need intensive care. ${ }^{3}$

Human-to-human transmission is thought to be mainly via saliva-associated respiratory droplets and direct contact transmission. However, the fecal-oral transmission is possible as SARS-CoV-2 was identified in the stool of infected patients. ${ }^{4}$

Aerosol and fomite transmission of SARS-CoV-2 is also possible as the virus can remain viable and infectious in aerosols for at least 3 hours and on surfaces for days (van Doremalen et al., 2020). 
Asymptomatic COVID-19 carriers' transmission possibility was also reported (Bai et al., 2020; C-C Lai et al., 2020). Real-time reverse transcription polymerase chain reaction (rRT-PCR) test is utilized for the qualitative detection of nucleic acid from SARS-CoV-2 in upper and lower respiratory samples obtained through nasopharyngeal and/or oropharyngeal swabs.

\section{Dental Aerosol and Splatter}

The terms "aerosol" and "splatter" in dentistry were introduced by Micik and colleagues in their pioneering work on aerobiology. They defined aerosols as particles $<50 \mu \mathrm{m}$ in diameter. These particles are small enough to stay airborne for an extended period before they settle on environmental surfaces or enter the respiratory tract of a patient. The smaller particles of an aerosol (0.5-10 $\mu \mathrm{m}$ in diameter) can lodge in the smaller passages of the lungs and alveoli and are thought to carry the greatest potential for transmitting infections associated with them. ${ }^{5}$

Micik and colleagues defined the term "splatter" as airborne particles larger than $50 \mu \mathrm{m}$ in diameter. They stated that these particles behaved in a ballistic manner which means that these particles or droplets are ejected forcibly from the operating site and arc in a trajectory similar to that of a bullet until they contact a surface or fall to the floor. These particles are too large to become suspended in the air and are airborne only for a brief period. ${ }^{6,7}$

The data suggest that the greatest airborne infection threat in dentistry comes from aerosols (particles $<50 \mu \mathrm{m}$ in diameter) production due to their ability to stay airborne and their potential to enter respiratory passages. ${ }^{8}$

\section{Composition of Dental Aerosols}

Qualitative and quantitative analysis of dental aerosols would be extremely difficult as the composition of aerosols probably varies with each patient and operative site. It is supposed that components of saliva, nasopharyngeal secretions, plaque, blood, tooth components, and any material used in the dental procedure, such as abrasives for air polishing and air abrasion, all are content in dental aerosols. In the past, studies usually concentrated on the number of bacteria present in dental aerosols; several recent studies have analyzed the presence of blood components in dental aerosols. ${ }^{9}$

\section{Sources of Airborne Contamination during Dental Treatment}

The potential sources of airborne contamination during any dental treatment are dental instrumentation, saliva and respiratory sources, and operative site. Contamination from dental instrumentation is the result of organisms on instruments and in Dental Unit Water Lines (DUWLs). Routine cleaning and sterilization procedures should eliminate contamination of all dental instruments except those being used with the current patient. The use of ADA-recommended methods to treat the DUWLs also should minimize or eliminate airborne contamination from the DUWLs. Because contamination from these sources is controlled relatively easily by following standard procedures, we do not discuss them in detail. ${ }^{10}$

The dental devices and procedures known to produce airborne contamination are ultrasonic and sonic scalers, air polishing, airwater syringe, tooth preparation with air turbine handpieces, tooth preparation with air.

\section{Possible Transmission Routes of 2019- nCoV in Dental Clinics}

Dental care settings carry the risk of infection transmission due to the specificity of its procedures, which involves face-to-face communication or direct transmission (cough, sneeze, and droplet inhalation transmission) and contact transmission (contact with oral, nasal, and eye mucous membranes). Some studies have shown that respiratory viruses can be transmitted from person to person through direct or indirect contact, or through coarse or small droplets, and 2019-nCoV can also be transmitted directly or indirectly through oral secretion like saliva. ${ }^{11}$

\section{COVID-19 Transmission and Dental Treatment}

SARS-CoV-2 has been isolated from the saliva of COVID-19 patients (To et al., 2020). ${ }^{12}$

Moreover, salivary gland epithelial cells can potentially be infected by SARS-CoV and become a major source of the virus in saliva (Liu et al.). ${ }^{13}$

Even after patient recovery, recusancy during the convalescence period was reported. ${ }^{14}$

This is plausible since the presence of some virus strains in saliva for as long as 29 days have been reported in the literature (Barzon et al., 2016; Zuanazzi et al., 2017). ${ }^{15}$

The potential routes for the spread of infection in a dental operatory are direct contact with body fluids of an infected patient, contact with environmental surfaces or instruments that have been contaminated by the patient, and contact with infectious particles from the patient that have become airborne. ${ }^{16}$

Also, the majority of routine dental procedures generate significant amounts of droplets and aerosols due to the utilization of devices and equipment such as ultrasonic scalers, air-water syringes, and air turbine handpieces. Also, use of extraoral radiographs needs to be preferred as compared to intraoral radiographs which may act as a possible source of infection.

\section{Methods of Reducing Airborne CONTAMINATION}

ADA defined dental emergencies as potentially life-threatening and require immediate treatment to stop ongoing tissue bleeding [or to] alleviate severe pain or infection. Various conditions include uncontrolled bleeding; cellulitis or a diffuse soft-tissue bacterial infection with intraoral or extraoral swelling that potentially compromises the patient's airway; or trauma involving facial bones that potentially compromises the patient's airway passage.

The aerosol created by the interaction of coolant water and ultrasonic vibrations or by compressed air and a rotary motion is visible to patients and dental personnel. During routine dental treatment aerosolized material produced will include viruses, blood, and supra- and subgingival plaque organisms at this time, it is impossible to determine the exact infection risk represented by aerosolized material. The potential for the spread of infection via an almost invisible aerosol, however, must be recognized and minimized or eliminated to the greatest extent feasible within a clinical situation.

To reduce any airborne contamination, we need to control the number of people in a certain area as well. The use of personal barrier protection such as gloves, eye protection, masks, will eliminate much of the danger inherent in splatter droplets arising from the operative site. 
Personal protection equipment (PPE) specifications ${ }^{17}$

\begin{tabular}{|c|c|}
\hline \multirow[t]{6}{*}{ N-95 Masks } & - Shape that will not collapse easily \\
\hline & - High filtration efficiency \\
\hline & - Good breathability, with expiratory \\
\hline & $\begin{array}{l}\text { - Quality compliant with standards for } \\
\text { medical N95 respirator: a. NIOSH N95, EN } \\
\text { 149FFP2, or equivalent }\end{array}$ \\
\hline & $\begin{array}{l}\text { - Fluid resistance: minimum } 80 \mathrm{~mm} \mathrm{Hg} \\
\text { pressure based on ASTM F1862, ISO 22609, } \\
\text { or equivalent }\end{array}$ \\
\hline & $\begin{array}{l}\text { - Quality compliant with standards for a } \\
\text { particulate respirator that can be worn with } \\
\text { a full-face shield }\end{array}$ \\
\hline $\begin{array}{l}\text { Triple-layer medical } \\
\text { mask }\end{array}$ & $\begin{array}{l}\text { Three-layered medical masks of non-woven } \\
\text { material with a nose piece, having filter } \\
\text { efficiency of } 99 \% \text { for } 3 \mu \mathrm{m} \text { particle size. a. } \\
\text { ISI specifications or equivalent }\end{array}$ \\
\hline \multirow[t]{6}{*}{ Face shield } & $\begin{array}{l}\text { - Made of clear plastic and provides good } \\
\text { visibility to both the wearer and the patient }\end{array}$ \\
\hline & $\begin{array}{l}\text { - Adjustable band to attach firmly around the } \\
\text { head and fit snuggly against the forehead }\end{array}$ \\
\hline & $\begin{array}{l}\text { May be re-usable (made of a material } \\
\text { which can be cleaned and disinfected) or } \\
\text { disposable }\end{array}$ \\
\hline & $\begin{array}{l}\text { - Quality compliant with the below standards, } \\
\text { or equivalent: }\end{array}$ \\
\hline & $\begin{array}{l}\text { - EU standard directive } 86 / 686 / E E C, \text { EN } \\
166 / 2002\end{array}$ \\
\hline & - ANSI/SEA Z87.1-2010 \\
\hline Goggles & $\begin{array}{l}\text { With transparent glasses, zero power, well- } \\
\text { fitting, covered from all sides with elastic } \\
\text { band/or adjustable holder }\end{array}$ \\
\hline \multirow{3}{*}{$\begin{array}{l}\text { Coverall (medium } \\
\text { and large)* }\end{array}$} & - Impermeable to blood and body fluids \\
\hline & - Single use \\
\hline & $\begin{array}{l}\text { - Quality compliant with following standard } \\
\text { a. Meets or exceeds ISO } 16603 \text { class } 3 \\
\text { exposure pressure, or equivalent }\end{array}$ \\
\hline \multirow[t]{8}{*}{ Gloves } & - Nitrile \\
\hline & - Powder-free \\
\hline & $\begin{array}{l}\text { - Outer gloves preferably reach mid-forearm } \\
\text { (minimum } 280 \mathrm{~mm} \text { total length) }\end{array}$ \\
\hline & - Different sizes (6.5 and 7) \\
\hline & $\begin{array}{l}\text { - Quality compliant with the below standards, } \\
\text { or equivalent: }\end{array}$ \\
\hline & $\begin{array}{l}\text { - EU standard directive 93/42/EEC Class I, } \\
\text { EN } 455\end{array}$ \\
\hline & $\begin{array}{l}\text { - EU standard directive 89/686/EEC } \\
\text { Category III, EN } 374\end{array}$ \\
\hline & - $\quad$ ANSI/SEA 105-2011 4. ASTM D6319-10 \\
\hline
\end{tabular}

\section{Preprocedural Mouth Rinse}

A meta-analysis showed that the use of preprocedural mouth rinse, including chlorhexidine (CHX), essential oils, and cetyl pyridinium chloride $(C P C)$, resulted in a mean reduction of $68.4 \%$ colonyforming units in the dental aerosol. ${ }^{18}$

The effect of preprocedural mouth rinse against coronavirus is still unknown, it has been proven that $\mathrm{CHX}$ is effective against several infectious viruses, including herpes simplex virus (HSV), human immunodeficiency virus (HIV), and hepatitis B virus (HBV) (Wood and Payne, 1998).

\section{Rubber Dam Isolation}

During dental treatment procedures that generate aerosols, a rubber dam provides barrier protection from the primary source and will virtually eliminate all pathogens emerging from respiratory and salivary secretions. Application of rubber dam during tooth cavity preparation has shown a significant reduction in the spread of microorganisms by $90 \%$ (Cochran et al., 1989). Rubber dam has to be applied in all aerosol-generating procedures. One disadvantage of using the rubber dam is that it is not feasible in procedures that require instrumentation sub-gingivally such as subgingival restoration and subgingival crown margin preparation.

\section{Removal/Filter of Contaminated Air}

There are several methods to remove/filter contaminated air in treatment areas; the two most commonly used devices include high-volume evacuator (HVE) and high-efficiency particulate arrestor (HEPA) filters.

\section{HVE Filter}

It is a suction device that helps remove air at a rate of up to $2.83 \mathrm{~m}^{3}$ per minute. It is the easiest way to remove dental aerosols as they are generated and could effectively decrease contamination caused by the operating site by $90 \%$ (Narayana et al., 2016). However, the device should be held at a proper distance (approximately 6-15 $\mathrm{mm}$ ) from the active ultrasonic tip of the scaler.

\section{Negative-pressure Isolation Rooms}

They require a minimum of 12 air changes of exhaust per hour and must maintain a minimum 0.01 -inch WC negative-pressure differential to the adjacent corridor whether or not an anteroom is utilized.

\section{HEPA Filter}

This air filtration device can remove $99.97 \%$ of the particles measuring $0.3 \mu \mathrm{m}$ in diameter. One disadvantage is that the filter may become a source of microbes if the retained microorganisms proliferate and enter back into the filtered air (Chuaybamroong et al., 2010). In addition, soiled HEPA filters are difficult to clean and expensive to replace (Day et al., 2018).

\section{Environmental Surface Disinfection}

Due to aerosol-generating procedures, droplets containing infective pathogens could be deposited onto surfaces. An analysis of 22 studies revealed that human coronaviruses, such as SARS and MERS, can persist on inanimate surfaces for up to 9 to 10 days. They can be efficiently inactivated by surface disinfects within 1 to 1.5 minutes. Surface disinfectants contain $62-71 \%$ ethanol, $0.5 \%$ hydrogen peroxide, and $0.1 \%(1 \mathrm{~g} / \mathrm{L}$ ) sodium hypochlorite (Kampf et al., 2020). Inanimate surfaces are disinfected after each patient visit, especially surfaces close to the operating areas.

\section{Teledentistry}

Remote facilitating of dental treatment, guidance, and education via the use of information technology instead of direct faceto-face contact with patients is teledentistry. Teleconsultation, telediagnosis, and telemonitoring are subunits of teledentistry 
that have important functions relevant in dental practice. There are many challenges to the acceptance of teledentistry by dentists as well as patients, which need to be addressed urgently in an era of the pandemic. ${ }^{19}$

\section{IDA Guidelines ${ }^{11}$}

- Post a sign at the entrance to the dental practice which instructs patients having symptoms of a respiratory infection (e.g., cough, sore throat, fever, sneezing, or shortness of breath) to reschedule their dental treatment appointment and call their physician. The same thing applies if they have had any of these symptoms in the last 24 to 48 hours.

- Reschedule appointments if your patients have traveled outside India in the last 2 weeks to an area affected by the coronavirus. These countries include China, Hong Kong, Iran, Italy, France, Spain, Germany, Japan, Singapore, South Korea, Taiwan, Thailand, Vietnam, or any other COVID-19 affected country in the world.

- Take a detailed travel and health history. Do not provide nonemergency or cosmetic dental treatment to the above patients and report them to the health department immediately. Screen patients for travel and signs, symptoms of infection when they update their medical histories.

- Incorporate questions about the new onset of respiratory symptoms into daily assessments of all patients.

- Take temperature readings as part of the routine assessment of patients before performing dental procedures.

- Take the contact details and address of all patients treated.

- Install physical barriers (e.g., glass or plastic windows) at reception areas to limit close contact with potentially infectious patients.

- Make sure the personal protective equipment being used is appropriate for the procedures being performed.

- Use a rubber dam when appropriate to decrease possible exposure to infectious agents.

- Use high-speed evacuation for dental procedures producing an aerosol.

- Autoclave hand-pieces after each patient.

- Have patients rinse with a $1 \%$ hydrogen peroxide solution before each appointment.

- Clean and disinfect public areas frequently, including door handles, chairs, and bathrooms.

- Post visual alerts icon (e.g., signs, posters) at the entrance and in strategic places (e.g., waiting areas, elevators, cafeterias) to provide patients with instructions (in appropriate languages) about hand hygiene, respiratory hygiene, and cough etiquette. Instructions should include how to use tissues to cover the nose and mouth when coughing or sneezing, to dispose of tissues and contaminated items in waste receptacles, and how and when to perform hand hygiene.

\section{Conclusion}

Dentists are at high risk of exposure to infectious diseases. The emergence of COVID-19 has brought new challenges and responsibilities to dental professionals. A good understanding of aerosol transmission and its implication in dentistry can help us identify and rectify negligence in daily dental practice. Knowledge and awareness and implementation of special precautions could prevent disease transmission from asymptomatic carriers.
These special precautions would not only help to limit the spread of COVID-19 but also serve as a guide for managing other respiratory diseases.

\section{References}

1. WHO, 2020a. WHO Virtual press conference on COVID-19. World Heal. Organ. https://www.who.int/docs/de375fault-source/coronaviruse/ transcripts/who-audio-emergencies coronavirus-press-conferencefull-and-final-11mar2020.pdf (ac377cessed 3.29.20).

2. Lai C-C, Liu YH, Wang C-Y, et al. Asymptomatic carrier state, acute respiratory disease, and pneumonia due to severe acute 336 respiratory syndrome coronavirus 2 (SARS-CoV-2): Facts and myths. J Microbiol Immunol Infect 2020;53(3):404-412. DOI: 10.1016/j. jmii.2020.02.012.

3. WHO, 2020c. Coronavirus disease 2019 Situation Report - 41 [WWW 383 Document]. World Heal. Organ. https://www.who.int/docs/ de384fault-source/coronaviruse/situation-reports/20200301-sitrep41385covid-19.pdf.

4. Holshue ML, DeBolt C, Lindquist S, et al. First case of 2019 novel coronavirus in the United States. N Engl J Med 2020;382(10):929-936. DOI: 10.1056/NEJMoa2001191.

5. Micik RE, Miller RL, Mazzarella MA, et al. Studies on dental aerobiology, I: bacterial aerosols generated during dental procedures. J Dent Res 1969;48(1):49-56. DOI: 10.1177/00220345690480012401.

6. Miller RL, Micik RE, Abel C, et al. Studies of dental aerobiology, II: microbial splatter discharged from the oral cavity of dental patients. J Dent Res 1971;50(3):621-625. DOI: 10.1177/00220345710500031701.

7. Micik RE, Miller RL, Leong AC. Studies on dental aerobiology, 3 : efficacy of surgical masks in protecting dental personnel from airborne bacterial particles. J Dent Res 1971;50(3):626-630. DOI: $10.1177 / 00220345710500031801$.

8. Hinds WC. Aerosol technology: Properties, behavior, and measurement of airborne particles. New York: Wiley; 1982. pp. 6-8.

9. Bentley CD, Burkhart NW, Crawford JJ. Evaluating spatter and aerosol contamination during dental procedures. JADA 1994;125(5):579-584. DOI: 10.14219/jada.archive.1994.0093.

10. Murdoch-Kinch CA, Andrews NL, Atwan S, et al. Comparison of dental water quality management procedures. JADA 1997;128(9):1235-1243. DOI: 10.14219/jada.archive.1997.0400.

11. https://www.ida.org.in/pdf/IDA_Recommendations_for_Dental_ Professionals_on_the_Coronavirus_Threat.pdf.

12. Tsang KK-W, Chik-Yan Yip OT-Y, Chan C, et al. Consistent detection of 2019 novel coronavirus in saliva. Infect Dis Clin 2020;71(15):841-843. DOI: https://doi.org/10.1093/cid/ciaa149.

13. Liu L, Wei $Q$, Alvarez $X$, et al. Epithelial cells lining salivary gland ducts are early target cells of 352 severe acute respiratory syndrome coronavirus infection in the 353 upper respiratory tracts of rhesus macaques. J Virol 2011;85(8):4025-4030. DOI: 10.1128/jvi.02292-10.

14. Chen D, Xu W, Lei Z, et al. Recurrence of positive SARS-CoV-2 RNA in COVID-19: a case report. J Infect Dis Int 2020;85(8):4025-4030. DOI: 10.1016/j.ijid.2020.03.003.

15. Barzon L, Pacenti M, Berto $A$, et al. Isolation of infectious zika virus from saliva and prolonged viral RNA shedding in a traveller returning from the Dominican Republic to Italy, january 2016. Euro Surveill 2016;21(10):301-359. DOI: 10.2807/1560-7917.ES.2016.21.10.30159.

16. Garner JS. Guideline for isolation precautions in hospitals. The hospital infection control practices advisory committee. Infect Control Hosp Epidemiol 1996;17(1):53-80. DOI: 10.2307/30142367.

17. https://www.mohfw.gov.in/pdf/Guidelinesonrationaluseof PersonalProtectiveEquipment.pdf.

18. Marui VC, Souto MLS, Rovai ES, et al. Efficacy of preprocedural mouthrinses in the reduction of microorganisms in aerosol: a systematic review. J Am Dent Assoc 2019;150(12):1015-1026.e1. DOI: 10.1016/j.adaj.2019.06.024.

19. Gha S. Teledentistry during COVID-19 pandemic. Diabetes Metab Syndr 2020;14(5):933-935. DOI: 10.1016/j.dsx.2020.06.029. 